A dietary protein deficiency can affect the susceptibility to the toxicity of drugs or other agents such as pesticides and herbicides (2). At the present time, there are no such studies relative to theophylline, although the usage of theophylline is now quite common in the neonatal intensive care environment. Many infants therein who are now receiving theophylline therapeutically are being dosed on a body weight basis without consideration of the nutritional status. Our data suggest that, in the animal model, the administration of theophylline in the presence of a compromised nutritional status may have effects not now apparent. We add our concern to that expressed by others (16) that methylxanthine administration may have previously unsuspected effects on the developing brain.

\section{REFERENCES AND NOTES}

1. Berlin, C. M.: Excretion of the methylxanthines in human milk. Semin. Perinatol., 5: 389 (1981).

2. Boyd, E. M.: Diet and drug toxicity. Clin. Toxicol., 2: 423 (1969).

3. Enesco, M. and Leblond, C. P.: Increase in cell number as a factor in the growth of the young male rat. J. Embryol. Exp. Morphol., 10: 530 (1962).

4. Keenan, E. J., Klase, P. A., and Thomas, J. A.: Effects of prolactin on DNA synthesis and growth of the accessory sex organs in male mice. Endocrinology, 109: 170 (1981).

5. Kuzemko, J. A. and Paala, J.: Apneic attacks in the newborn treated with aminophylline. Arch. Dis. Child., 48: 404 (1973).

6. Lowry, O. H., Rosebrough, N. J., Farr, A. L., and Randall, R. J.: Protein measurement with folin phenol reagent. J. Biol. Chem., 193: 265 (1951).

7. Metha, S., Kalsi, H. K., Jajaraman, S., and Mathers, V. S.: Chloramphenicol metabolism in children with protein-calorie malnutrition. Am. J. Clin. Nutr., 28: 977 (1975).

8. Nakamoto, T. and Miller, S. A.: Effect of protein-energy malnutrition on the growth of mandible and long bone in newborn male and female rats. $J$. Nutr., 107: 983 (1977).

9. Nebron, R. M., Resnick, M. D., and Halstrum, W. J.: Developmental outcome of premature infants treated with theophylline. Dev. Pharmacol. Ther., 1: 274 (1980).

10. Newberne, P. M., Gross, R. L., and Roe, D. A.: Drug, toxin, nutrient interactions. World Rev. Nutr. Diet., 29: 130 (1978).

11. Pastorova, B., Sova, O., and Burda, J.: Incorporation of ${ }^{14} \mathrm{C}$-thymidine into liver and brain DNA of protein-deficient rats. Physiol. Bohemoslov., 27: 69 (1978).

12. Prasad, A. S., Dumouchell, E., Kovich, D., and Oberleas, D.: A simple fluorometric method for the determination of RNA and DNA in tissue. $J$ Lab. Clin. Med., 80: 598 (1972).

13. Varma, D. R.: Influence of dietary protein on the anti-inflammatory and ulcerogenic effects and on the pharmacokinetics of pheylbutazone in rats. $\mathbf{J}$ Pharmacol. Exp. Ther., 211: 338 (1979).

14. Winick, M. and Brasel, J.: Nutrition and Cell Growth. In R. S. Goodhart and M. E. Shills: Modern Nutrition in Health and Disease. p. 603 (Lea and Febiger, Philadelphia 1980).

15. Winick, M. and Noble, A.: Cellular response in rats during malnutrition at various ages. Dev. Biol., 12: 451 (1965).

16. Volpe, J. J.: Effects of methylxanthine on lipid synthesis in developing neural systems. Semin. Perinatol., 5: 395 (1981).

17. Based on the average body weight and the mean daily food intake in the dam fed each of the different diets during day 1 to 15 of postnatal period, the amount of theophylline was adjusted to $2 \mathrm{mg} / 100 \mathrm{~g}$ of body weight.

18. Requests for reprints should be addressed to: Dr. Griffith E. Quinby, Jr., Department of Pediatrics, Louisiana State University Medical Center, 1542 Tulane Avenue, New Orleans, Louisiana 70112.

19. Received for publication June 16, 1983.

20. Accepted for publication September 21, 1983.

\title{
Iron Deficiency in the Rat: Effects on Neutrophil Activation and Metabolism
}

\author{
BRUCE MACKLER, ${ }^{(20)}$ RICHARD PERSON, HANS OCHS, AND C. A. FINCH \\ Department of Pediatrics and Medicine, and the Center for Child Development and Mental Retardation, \\ University of Washington, Seattle, Washington, USA
}

\begin{abstract}
Summary
Studies were performed to determine the effects of iron deficiency in the rat on neutrophil activation and on levels of neutrophil myeloperoxidase and cytochrome $b$. The period of time required for neutrophil activation was not significantly affected by iron deficiency, but the maximum rates of respiration attained after activation were markedly lower $(60 \%$ decrease) in irondeficient neutrophils than in control cells. The myeloperoxidase activity of neutrophils from iron-deficient rats was also markedly decreased (approximately 75\%) compared with the activity of control cells; however, the concentration of cytochrome $b$ in the neutrophils was unaffected by iron deficiency.
\end{abstract}

\section{Abbreviations}

NBT, nitro blue tetrazolium

PMA, phorbol myristate acetate
A number of investigators have reported that iron deficiency in human subjects is associated with increased rates of infections, and that after treatment with iron supplements the high incidence of infections disappears [reviews by Chandra (4) and Strauss (18)]. Other investigators $(4,11)$ have shown that iron deficiency is associated with impaired immune functions, and that the abnormalities in immunocompetence appear to be reversible and to be related to the iron status as determined by transferrin saturation rather than hemoglobin concentration, suggesting that tissue deficiencies of iron-containing enzyme systems may be responsible. Chandra (3) demonstrated that neutrophils from iron-deficient children were defective in bactericidal activity and showed reduced NBT reduction after induction of phagocytosis. In addition, Higashi et al. (9) have reported studies which suggest that levels of myeloperoxidase may be lowered in the neutrophils of some patients with severe iron deficiency.

The present studies were undertaken to determine the iffects 
of severe iron deficiency in the rat on neutrophil activation (respiratory burst) and on levels of myeloperoxidase (an ironcontaining enzyme) because both systems have been shown to be of major importance in bacterial killing by neutrophils (11).

\section{MATERIALS AND METHODS}

Male Sprague-Dawley rats were obtained at 4 wk of age, 1 wk after weaning. Rats to be made iron deficient were given a low iron diet, prepared in our laboratory as described by ICN Nutritional Biochemicals, Cleveland, Ohio, that contained $5-8 \mathrm{mg} / \mathrm{kg}$ of elemental iron. After $6 \mathrm{wk}$ on this diet, hemoglobin concentrations were determined and studies were performed only on rats with hemoglobin concentrations of less than $7 \mathrm{~g} / 100 \mathrm{ml}$ blood. Previously, we have shown that the low hemoglobin concentrations found in rats fed the low iron diet were accompanied by greatly lowered levels of plasma iron and increased total iron binding capacity and that the anemia was of a microcytic type $(5,6,16)$. The control groups were fed the low iron diet during the experimental period, but received weekly intraperitoneal injections of $5 \mathrm{mg}$ of iron in the form of iron dextran (Imferon, Merrell-National Labs). All animals were allowed food and water ad libitum. The iron-deficient rats consumed over $90 \%$ of the amount of diet eaten by the control animals and, on the average, were approximately only $5 \%$ smaller by weight than the control animals suggesting that severe caloric malnutrition was not present.

Blood was drawn from the aortas of ether-anesthetized rats into syringes containing preservative-free heparin $(50 \mathrm{U} / \mathrm{ml}$ blood). Some blood was allowed to clot and serum was obtained by centrifugation. The heparinized blood from 3-4 rats (approximately $40-50 \mathrm{ml}$ ) was pooled and diluted with an equal amount of Hanks balanced salt solution (14). Neutrophils were separated as described by Boyum (1) with the following modifications. A ficoll-hypaque solution of specific gravity 1.091 was prepared by mixing solutions of $34 \%$ hypaque and $9 \%$ ficoll to obtain the proper specific gravity. Ten milliliters of the diluted blood was carefully layered over $4 \mathrm{ml}$ of the ficoll-hypaque solution in 15$\mathrm{ml}$ conical centrifuge tubes which were then centrifuged at room temperature for $25 \mathrm{~min}$ at $1300 \mathrm{rev} / \mathrm{min}(400 \mathrm{~g})$ in a type 253 head in an International PR6000 centrifuge. The supernatant solution including the ficoll-hypaque layer and lymphocytes and platelets was carefully removed by aspiration leaving the neutrophils layered on top of the red blood cells. Six milliliters of a solution containing 3\% dextran (average molecular weight, 264,000 ) and $0.9 \% \mathrm{NaCl}$ were added to each tube. The contents were mixed by inverting the tubes several times and the cell suspensions were incubated for $20 \mathrm{~min}$ at $37^{\circ} \mathrm{C}$. The supernatant solution containing the neutrophils (and some red blood cells) was separated from the settled red blood cells and centrifuged at room temperature for $10 \mathrm{~min}$ at $1300 \mathrm{rev} / \mathrm{min}$ in the PR6000 centrifuge. For each experiment, the pellets containing the neutrophils from approximately $40 \mathrm{ml}$ of blood were gently suspended in $30 \mathrm{ml}$ of a solution containing $0.83 \%$ ammonium chloride, $0.1 \% \mathrm{KHCO}_{3}$ and $0.004 \%$ EDTA and were incubated $10 \mathrm{~min}$ at $37^{\circ} \mathrm{C}$ to lyse the red cells before centrifugation in a PR6000 centrifuge at room temperature for $10 \mathrm{~min}$ at $1300 \mathrm{rev} /$ min. The pellet containing the neutrophils was resuspended in the ammonium chloride solution, and the incubation and centrifugation steps were repeated. The pellet, which consisted of neutrophils free of red cells, was suspended gently in a solution containing $0.25 \mathrm{M}$ sucrose and $0.02 \mathrm{M}$ Tris of $\mathrm{pH} 7.4$ and centrifuged again at room temperature for $10 \mathrm{~min}$ at $1300 \mathrm{rev} /$ min. The pellet (containing 1-2 mg of protein and approximately $10^{7}$ cells) was suspended gently in $0.3-0.5 \mathrm{ml}$ of the sucrose-Tris solution and used for the activation studies. Neutrophil preparations to be used for myeloperoxidase and cytochrome $b$ determinations were incubated with the ammonium chloride solution two additional times for 2-min periods in order to remove hemoglobin completely, and the cells were suspended in $1.0 \mathrm{ml}$ of a solution containing $0.25 \mathrm{M}$ sucrose, $0.05 \mathrm{M}$ Tris, and $1.0 \mathrm{~m}$ $M$ EDTA of pH 8.0. The cell suspension was placed in ice and sonicated in 10-sec bursts for a total of 2 min at $140 \mathrm{~W}$ with the small probe of a Braunsonic Model 1510 Ultrasonicator. The suspension (containing $1-2 \mathrm{mg}$ of protein $/ \mathrm{ml}$ ) was kept at $0-5^{\circ} \mathrm{C}$ and assayed for myeloperoxidase at $37^{\circ} \mathrm{C}$ by the method of Himmelhoch et al. (10). Concentrations of cytochrome $b$ were determined from difference spectra (dithionite reduced minus oxidized) of the preparations performed by means of a recording Aminco DW-2 spectrophotometer at $25^{\circ} \mathrm{C}$ using the millimolar extinction coefficient of $20.0(562-570 \mathrm{~nm})$ for cytochrome $b$ (2).

Studies of neutrophil activation were performed polarographically at $37^{\circ} \mathrm{C}$ with a Clark oxygen electrode (Yellow Springs Instrument $\mathrm{Co}$, Yellow Springs, $\mathrm{OH}$ ) fitted to a closed glass thermostated chamber (Gilson Instrument Co., Madison, WI). The assay mixture contained $0.80 \mathrm{ml}$ of a solution of $0.25 \mathrm{M}$ sucrose and $0.02 \mathrm{M}$ Tris ( $\mathrm{pH} 7.4$ ), $0.20 \mathrm{ml}$ of fresh serum (prepared from the same rat blood as the neutrophils), $0.20 \mathrm{ml}$ of the intact neutrophil suspension and $0.66 \mathrm{ml}$ of Hanks solution. After the rate of oxygen uptake of the unactivated cell suspension was determined, $4 \mathrm{mg}$ of PMA (in $0.04 \mathrm{ml}$ of the sucrose-Tris solution) was added to the chamber to activate the cells. The time intervals between the addition of PMA and the start of activation and the maximal activation were recorded and the maximal rate of oxygen uptake was determined.

Protein was determined by the method of Lowry et al. (12). Hemoglobin was determined as cyanmethemoglobin with standards employed for calibration (Hycel, Inc., Houston, TX). Statistical analyses were performed by standard methods of variance as described by Snedecor and Cochran (17).

Heparin, Tris, EDTA, and 4,1-phorbol 12-myristate 13-acetate were obtained from Sigma Chemical Co., St. Louis, MO.

\section{RESULTS AND DISCUSSION}

The effects of iron deficiency on the respiration of intact rat neutrophils before and after activation with PMA is shown in Table 1. As described in the Table, the rates of respiration of the unactivated neutrophils and the time intervals necessary for activation to occur were not significantly affected by iron deficiency. But, the maximum rates of respiration achieved after activation of neutrophils from iron-deficient rats were markedly and significantly lower (60\% decrease) than those of control cells. The findings suggest that iron deficiency may affect the respiratory burst of neutrophils by decreasing the activity or concentration of iron-containing oxidative enzyme systems of the cells and not by interruption of the activation process.

Studies were next performed to determine the effects of iron deficiency on the concentrations of cytochrome $b$ (a heme containing compound) in rat neutrophils because recent work by other investigators suggests that it is active in the respiratory burst of neutrophils $(8,15)$. In addition, concentrations of myeloperoxidase, an important bactericidal system (12) which contains iron, were also determined in the cells. As shown in Table 2 myeloperoxidase activity was decreased (approximately $75 \%$ ) in the iron-deficient rat neutrophils; however, the cytochrome $b$ concentration in the cells was unaffected by iron deficiency.

The results reported above demonstrate that two important bactericidal systems in neutrophils (the oxidative systems comprising the respiratory burst and myeloperoxidase) are reduced in iron deficiency, and suggest a partial explanation or biochemical basis for the many reports of increased rates of infection in iron-deficient human subjects $(4,11,18)$. It is also noteworthy that the concentration of cytochrome $b$ in the neutrophils was not affected by iron deficiency, suggesting that the superoxidegenerating oxidase (18) of the neutrophils (which appears to be responsible for the respiratory burst) may be a non-heme ironcontaining enzyme and depleted in states of iron deficiency. The finding that concentrations of cytochrome $b$ in the neutrophils 
Table 1. Effects of iron deficiency on the respiration of intact rat neutrophils before and after activation with phorbol myristate acetate*

\begin{tabular}{|c|c|c|c|c|c|}
\hline \multirow[b]{2}{*}{ Experiment } & \multirow[b]{2}{*}{$\begin{array}{c}\text { Hemoglobin } \\
(\mathrm{g} / 100 \mathrm{ml} \text { blood })\end{array}$} & \multicolumn{2}{|c|}{$\begin{array}{c}\text { Oxygen consumption } \\
\text { (n atoms } \mathrm{O}_{2} \cdot \mathrm{mg} \mathrm{protein}^{-1} \cdot \mathrm{min}^{-1} \text { ) }\end{array}$} & \multicolumn{2}{|c|}{ Activation time } \\
\hline & & Unactivated & Activated & $\begin{array}{l}\text { To start of } \\
\text { increased } \\
\text { respiration }\end{array}$ & $\begin{array}{l}\text { To maximum } \\
\text { respiration }\end{array}$ \\
\hline Control & $15.3 \pm 0.6$ & $10.4 \pm 1.2$ & $79.2 \pm 10.7$ & $88 \pm 5$ & $183 \pm 25$ \\
\hline Iron deficient & $6.0 \pm 0.1$ & $8.8 \pm 2.0$ & $34.2 \pm 2.8$ & $105 \pm 8$ & $167 \pm 27$ \\
\hline
\end{tabular}

* Each value represents the mean $\pm \mathrm{SE}$ of at least six experiments.

Table 2. Effects of iron deficiency on the concentrations of myeloperoxidase and cytochrome $\mathrm{b}$ in rat neutrophils*

\begin{tabular}{lccc}
\hline Experiment & $\begin{array}{c}\text { Hemoglobulin } \\
(\mathrm{g} / 100 \mathrm{ml} \text { blood })\end{array}$ & $\begin{array}{c}\text { Myeloperoxidase } \\
\text { activity } \dagger \\
(\mathrm{U} / \mathrm{mg} \text { protein })\end{array}$ & $\begin{array}{c}\text { Cytochrome } b \\
\text { (nMol/mg pro- } \\
\text { tein) }\end{array}$ \\
\hline $\begin{array}{l}\text { Control } \\
\begin{array}{c}\text { Iron defi- } \\
\text { cient }\end{array}\end{array}$ & $15.6 \pm 0.5$ & $70.2 \pm 14.4$ & $0.0780 \pm 0.0086$ \\
$P$ value & $5.8 \pm 0.2$ & $18.7 \pm 3.4$ & $0.0739 \pm 0.0033$ \\
\hline
\end{tabular}

* Each value represents the mean $\pm \mathrm{SE}$ of at least six experiments for myeloperoxidase and four experiments for Cytochrome $b 245$.

+ One unit of activity was equal to an optical density change of 1.0 per minute.

were not affected by iron deficiency is not unique because we have previously shown that cytochrome concentrations in brain and heart muscle are unaffected by iron deficiency $(7,13)$.

\section{REFERENCES AND NOTES}

1. Boyum, A.: Isolation of mononuclear cells and granulocytes from human blood. Scand. J. Clin. Lab. Invest., 2l(suppl. 97): 77 (1968).

2. Chance, B. and Williams, G. R.: Respiratory enzymes in oxidative phosphorylation. II. difference spectra. J. Biol. Chem., 217: 395 (1955).

3. Chandra, R. K.: Reduced bactericidal capacity of polymorphs in iron deficiency. Arch. Dis. Child. 48: 864 (1973).

4. Chandra, R. K., Au, B., Woodford, G., and Hyam, P.: Iron status, immune response and susceptibility to infection. In: Iron Metabolism. Ciba Foundation Symposium 51. pp. 249-268 (Elsevier/Excerpta Medica/North-Holland, New York, 1977).

5. Finch, C. A., Gollnick, P. D., Hlastala, M. P., Miller, L. R., Dillman, E., and Mackler, B.: Lactic acidosis as a result of iron deficiency. Am. Soc. Clin. Invest., 64: 129 (1979).

6. Finch, C. A., Huebers, H. A., Miller, L. R., Josephson, B. M., Shepard, T. H., and Mackler, B.: Fetal iron balance in the rat. Am. J. Clin. Nutr. 37: 910 (1983).

7. Finch, C. A., Miller, L. R., Inamdar, A. R., Person, R., Seiler, K., and Mackler, B.: Iron deficiency in the rat. Physiological and biochemical studies of muscle dysfunction. J. Clin. Invest. 58: 447 (1976).

8. Gabig, T. G., Schervish, E. W., and Santinga, J. T.: Functional Relationship of the Cytochrome $b$ to the Superoxide-generating Oxidase of Human Neutrophils. J. Biol. Chem., 257: 4114 (1982)

9. Higashi, O., Sato, Y., Takamatsu, H., and Oyama, M.: Mean cellular peroxidase (MCP) of leukocytes in iron deficiency anemia. Tohku J. Exp. Med., 93: 105 (1967).

10. Himmelhoch, S. R., Evans, W. H., Mage, M. G., and Peterson, E. A.: Purification of myeloperoxidases from the bone marrow of the guinea pig. Biochemistry, 8: 914 (1969).

11. Klebanoff, S. and Robert A. Clark: The Neutrophil: Function and Clinical Disorders. (North Holland Publishing, 1978).

12. Lowry, O. H., Rosebrough, N. J., Farr, A. L., Randall, R. J.: Protein measurement with the Folin phenol reagent. J. Biol. Chem., 193: 265 (1951).

13. Mackler, B., Person, R., Miller, L. R., Inamdar, A. R., and Finch, C. A.: Iron deficiency in the rat: biochemical studies of brain metabolism. Pediatr. Res., 11: 217 (1978).

14. Paul, J.: Cell and Tissue Culture. p. 81 (Williams and Wilkins Company, Baltimore, 1960).

15. Segal, A. W., Cross, A. R., Garcia, R. C., Borregaard, N., Valerius, N. H., Soothill, J. F., and Jones, O. T. G.: Absence of cytochrome $b_{245}$ in chronic granulomatous disease. A multicenter european evaluation of its incidence and relevance. N. Engl. J. Med., 308: 245-251, (1983).

16. Shepard, T. H., Mackler, B., and Finch, C. A.: Reproductive studies in the iron-deficient rat. Teratology, 22: 329 (1980)

17. Snedecor, G. W., and Cochran, W. G.: Statistical Methods. 6th ed., pp. 258298 (Iowa State University Press, Ames, 1974).

18. Strauss, R. G.: Iron deficiency, infections, and immune function: a reassessment. Am. J. Clin. Nutr., 31: 660 (1978).

19. The authors wish to acknowledge many helpful discussions with Dr. Ralph Wedgwood.

20. Requests for reprints should be addressed to: Dr. Bruce Mackler, University of Washington, Department of Pediatrics, RD-20, Seattle, WA 98195.

21. This research was supported in part by grants HD-15915, GM-23006, HD02274, HD/AI-17427, and HL-06242.

22. Received for publication April 19, 1983.

23. Accepted for publication September 8, 1983. 